\title{
Simple Terrarium Teaching Aid for Guided Inquiry Learning Model: The Development of Learning Instruments to Students' Concept Understanding in Global Warming and Environmental Awareness
}

\author{
Najda Aliyatun Naezak ${ }^{(1)^{*}}$, Erna Noor Savitri ${ }^{(2)}$, Fidia Fibriana ${ }^{(3)}$ \\ (1) Universitas Negeri Semarang, Indonesia \\ (2) Universitas Negeri Semarang, Indonesia \\ (3) Universitas Negeri Semarang, Indonesia; Songkla University Thailand, Thailand \\ *Correspondence to: najdaaliyatun22@gmail.com
}

\begin{abstract}
This research aims to determine the feasibility and characteristics of the guided inquiry learning model assisted by a simple terrarium on students' concept understanding and environmental awareness in the global warming topic of study. The research and development $(\mathrm{RnD})$ method by analysis, design, development, implementation, and evaluation (ADDIE) was performed. The data collection instruments used were observation sheets, expert validation sheets, and questions. The teaching and learning instruments were declared feasible and ready for application with a few revisions based on the validation results. The n-gain analysis of increasing students' conceptual understanding was in the high category at 0.76 . The percentage of observations regarding environmental awareness increased at each successive meeting. The first meeting was $39.06 \%$, the second meeting was $63.12 \%$, and the third meeting was $89.37 \%$. In conclusion, the guided inquiry learning model assisted by a simple terrarium is feasible to improve students' conceptual understanding and environmental virtue ethics.
\end{abstract}

Keywords: learning model; students' character; teaching set

Recommended citation: Naezak, N. A., Savitri, E. N., \& Fibriana, F. (2021). Simple Terrarium Teaching Aid for Guided Inquiry Learning Model: The Development of Learning Instruments to Students' Concept Understanding in Global Warming and Environmental Awareness. Journal of Innovation in Educational and Cultural Research, 2(2), 51-59.

\section{INTRODUCTION}

Science learning is learning through a systematic process using scientific methods. Science learning provides students the opportunity to gain a learning experience through experiments and directly observe natural phenomena. However, since the Covid-19 cases began to increase in Indonesia, schools' learning system has changed to distance learning. The policy was issued through Circular Number 4 of 2020 concerning the implementation of Education Policy in the Emergency of the Spread of Coronavirus Disease (Covid-19) dated March 24, 2020, where students are encouraged to carry out the teaching and learning process from home through online learning (Pusdiklat Pegawai Ministry of Education and Culture, 2020). One of the fundamental policies is how students learn and how to teach educators that impact students and educators' behavior in the learning process.

Students must adapt to existing situations by changing learning styles because learning material is delivered online. The online learning system requires students and educators to be technology literate because all learning activities are delivered using social media. Social media that can help implement the learning process include WhatsApp, Google classroom, Zoom meeting, and Youtube. Besides, educators must be more creative and innovative in delivering learning materials to achieve learning goals even though they are carried out online. Therefore, the learning process must be appropriately planed through learning instruments to achieve learning objectives.

Learning instruments are a set of learning resources that allow students and teachers to carry out learning activities (Tanjung \& Nababan, 2019). Learning instruments in schools consist of a syllabus, lesson plans, worksheets, teaching materials, media, and evaluation tools. These learning instruments must be developed based on current related conditions. Learning instruments that follow the development stage are expected to produce a valid, feasible, useful, and practical learning instrument (Yunita, 2016). The development of learning instruments using learning models can increase the active role and students' understanding. In addition to knowledge, the development of learning instruments is also expected to produce good character, one of which is environmental awareness. The character of environmental 
awareness is essential because it is closely related to life continuity. The character of environmental awareness should be taught to students from the earliest possible. The young generation educated with knowledge and insight about the importance of maintaining environmental safety will have a deep concern for the environment, leading to behavior to preserve the environment (Martini, 2019).

Based on State Junior High School 32 Semarang observation results, the learning equipment components consisting of the syllabus, lesson plans, and student worksheets were developed, but the equipment components have not been matched to the 2013 Curriculum. Theoretical learning was accompanied by a collection of questions and did not show student learning activities scientifically and was made by the teacher. The evaluation tool in the form of test questions used to determine students 'abilities consists of simple questions that may not improve students' critical thinking ability. Meanwhile, the lesson plans were not in the various learning models; thus, the learning method was not student-centered. These learning instrument' shortcomings resulted in a lack of student achievement, as evidenced by the student's average semester final test score of 66. Low student achievement signifies that students' understanding of the concept of the material was low. According to the preliminary study, the poor understanding of the concept was caused by several factors, including that students often misunderstood the problems' true meaning. Students only learned the procedures needed to solve problems based on textbooks, not based on their thinking ability. Students solved problems using memorization methods, and that they could not apply this knowledge in everyday life. The observations also showed that the character of students' environmental awareness was still low, as evidenced by students' attitude who were still littering, did not care about classroom cleanliness, and did not take care of plants in the school environment. In short, one of the factors influencing the students' low environmental awareness character was the lack of media use in the learning process. The teacher's learning media was in printed form so that students were less able to describe abstract material. As a result, students could not apply the material or concepts they have learned in everyday life.

In fact, the global warming topic is an abstract study material representing a phenomenon with several adverse environmental impacts. Therefore, the role of the learning media is needed in its delivery. Students who have studied global warming material are expected to prevent more severe environmental damage and have the self-awareness to their environment. Based on these problems, it is crucial to develop learning instruments and media to improve students' understanding of the concept and character of environmental awareness. The guided inquiry learning model is a learning model that makes students involve themselves in discovering the principles and concepts of the material they are learning based on their experiences and experiments (Ismail et al., 2019). The guided inquiry learning model emphasizes students in the process of finding and finding concepts. According to the research results of Widyawati et al. (2019), guided inquiry learning effectively improves students' concept understanding. The teacher acts as a facilitator and guides students to support the learning process can fulfill the expected learning objectives. Therefore, the use of guided inquiry is preferred to be applied.

Apart from the learning model, the learning process is also required to optimize the learning media's role. Rahman (2019) states that the media is an intermediary or messenger for a message from sender to the recipient that can stimulate student interest in learning. The use of media can support the learning process, mate it easier for students to understand learning instruments, and improve student learning outcomes (Sari, 2019). Learning media provided to students should be real and concrete so that students can understand a concept. A simple terrarium is a medium that can be used as an alternative in learning because it can describe an abstract material. Cahayadi \& Ulung (2015) states that terrarium is a container containing several plants. A simple terrarium can imitate the earth's conditions caused by global warming in a more real way. Students will know the processes, causes, and impacts of global warming to understand better the dangers and ways to tackle global warming.

Based on this description, this research aimed to analyze the feasibility of the guided inquiry model learning instrument facilitated by a simple terrarium to instill environmental virtue ethics in junior high school students. The characteristics of concept understanding and the characters of students after learning processes are also described in this paper. 


\section{METHODS}

\section{Research Design and Participants}

The research and Development $(\mathrm{RnD})$ by analysis, design, development, implementation, and evaluation (ADDIE) method was employed in this study to develop and test the product's effectiveness. The research was conducted at the Faculty of Mathematics and Natural Sciences, Universitas Negeri Semarang, and State Junior High School 32 Semarang. The research was conducted during the odd semester of 2020/2021. The research subjects for the development of this learning instrument were class IX students.

\section{Research Instruments}

The research instruments consist of a validation sheet to measure the feasibility of developing the learning instruments and the readability questionnaire sheet to determine the instrument's readability. Next, the problems were given to the students to test their understanding of the concept of the global warming study topic. At the same time, the observation sheet was employed to measure environmental awareness.

\section{Data Collection}

The methods for collecting data in this development research are as follows.

\section{Documentation Method}

The documentation method was used as a data collector when researchers carried out data collection activities and research activities.

\section{Test Method}

The test method was used to determine students' understanding of concepts. Questions related to the global warming study topic were given to students based on understanding indicators. The questions consist of 10 problems with a short essay type of description to answer the questions and have met The type of test used in this study is a description of 10 questions that have met validity, reliability, distinguishing ability, and difficulty level.

\section{Questionnaire Method}

The questionnaires used in this study were: (1) the expert validity questionnaire was used at the design validation stage to test the appropriateness of the learning instruments (2) the student and teacher readability questionnaire for the learning instruments being developed.

\section{Observation Method}

The observation method was used in the learning process to determine the character of environmental awareness through the observation sheet.

\section{Data Analysis}

\section{Eligibility of Learning Instruments}

The appropriateness of the learning instruments was measured based on the validation results of five validators. The results of the validation were then analyzed using a formula:

$\mathrm{P}=$ the percentage of score obtained

$$
P=\frac{f}{N} \times 100 \%
$$

$f=$ the number of scores obtained

$\mathrm{N}=$ the maximum number of scores 
The percentage score results were then converted into the expert validation assessment criteria based on Table 1.

Table 1. Criteria of Validation Assessment

\begin{tabular}{cc}
\hline Percentage $(\%)$ & Criteria \\
\hline $81.25<$ score $\leq 100$ & Very Appropriate \\
$62.50<$ score $\leq 81.25$ & Appropriate \\
$43.75<$ score $\leq 62.50$ & Somewhat Appropriate \\
$25.00<$ score $\leq 43.75$ & Not Very Appropriate \\
$0.00 \leq 25$ & Not Appropriate \\
\hline
\end{tabular}

\section{Students' Concept Understanding Analysis}

Increased understanding of students' concepts can be seen based on the pretest and posttest scores using $\mathrm{n}$-gain. The formula for calculating the average $\mathrm{n}$-gain is:

$$
<\mathrm{g}>=\frac{\text { score of postest }- \text { score of pretest }}{\text { maximum score }- \text { score of pretest }}
$$

\section{Environmental Awareness Character Analysis} equations:

The results of observations of environmental awareness for each indicator were analyzed using

$$
P=\frac{f}{N} \times 100 \%
$$

\section{RESULT AND DISCUSSION}

\section{Analysis Stage}

At this stage, an analysis of the learning instruments was carried out. The observation results show that the learning instrument components consisting of the syllabus, lesson plans, and worksheets have been developed. However, the contents were not adjusted following the 2013 Curriculum. Low student achievement signifies that students' understanding of the concept of the material was lacking. Another factor that affects students' poor understanding of concepts is the lack of media use in the learning process. The media was used in a printed form, and students were less able to describe abstract material. The indirect use of instructional media can also function to improve and instill student character. One of the characters that arise from the use of media is the character of environmental virtue ethics. It follows the problems found based on the results of environmental awareness and care for the character. Therefore, after analyzing the learning instrument, a problem was found to understand the concept and character of students' environmental awareness. Social media selection factors in knowledge transfer must also be considered for online learning scheme. The selection of the social media platform for learning was also crucial because complex social media affected the students' motivation to study online.

\section{Design Stage}

At this stage, solutions to the analysis stage problems by conducting literature studies were performed. The problems were used to design learning instruments with a guided inquiry model assisted by a simple terrarium. The guided inquiry learning model has new characteristics to direct students to seek and discover a concept by themselves actively. In this model, the subject content is not given in the classroom initially, and the teacher acts as a guidance and facilitator in the learning processes (Suparmi, 2018). Therefore, the selection of this learning model was suitable for the online learning system. Also, WhatsApp, Zoom meeting, Google Classroom, and Youtube were employed as the platform for online knowledge transfer in this research. These apps' selection was based on several criteria, including easiness, accessibility, simplicity, and use of Android OS apps. Zoom meeting was utilized as a platform for teaching and learning processes, whereas Youtube was employed to upload learning materials and videos. Besides, WhatsApp and Google Classroom applications were applied to provide assignments and learning materials for students. 


\section{Development Stage}

At this stage, the initial framework of learning instruments was developed. The learning instruments, including syllabus, lesson plan, worksheets, and evaluation instruments, were constructed using the guided inquiry model. Simple terrarium learning media was designed and assembled to facilitate students' learning processes to instill understanding and environmental awareness. Then, five expert validators validated the learning instruments and media. The results are as follows:

\section{Syllabus}

A guided inquiry-based syllabus on the global warming study topic was developed and validated by the experts. The results of validation and assessment are presented in Table 2.

Table 2. Results of Syllabus Validation

\begin{tabular}{cccccc}
\hline \multirow{2}{*}{ Rated aspect } & \multicolumn{5}{c}{ Assessment Score } \\
\cline { 2 - 6 } & V1 & V2 & V3 & V4 & V5 \\
\hline Completeness of Syllabus Components & 3.67 & 3 & 2.67 & 4 & 4 \\
Language & 3 & 2 & 3 & 4 & 3.5 \\
Time & 4 & 3 & 3 & 3 & 3 \\
\hline
\end{tabular}

Average of All Aspects: 3.3

Average of Percentage: $82.5 \%$

Category of Syllabus: Very Appropriate

\section{Lesson plan}

The lesson plan is a systematic design for direct teaching and learning activities to achieve predetermined learning objectives. The lesson plan was arranged in 4 meetings to cover the topic of global warming. Students worked on the pretest questions in the first meeting to determine the students' initial knowledge, followed by the greenhouse effect subtopic. Students were given material about the causes and effects of global warming in the second and third meetings. In the fourth meeting, the teacher delivered material about efforts to prevent and cope with global warming issues and ended with working on posttest questions. The results of the lesson plan validation are presented in Table 3.

Table 3. Results of The Lesson Plan Validation

\begin{tabular}{cccccc}
\hline \multirow{2}{*}{ Rated aspect } & \multicolumn{5}{c}{ Assessment Score } \\
\cline { 2 - 6 } & V1 & V2 & V3 & V4 & V5 \\
\hline Formulation of Learning Objectives & 3.67 & 3 & 3 & 4 & 4 \\
Contents Served & 3.4 & 2.4 & 2.8 & 3.6 & 3.4 \\
Time & 3 & 3 & 2.5 & 3 & 3 \\
\hline Average of All Aspects: & 3.2 & & \\
Average of Percentage: $80 \%$ & & \\
Category of Lesson Plan: Appropriate
\end{tabular}

\section{Worksheets}

Student worksheets are assignment sheets consisting of a series of questions and information designed to guide students to understand complex ideas as they systematically work through them. The worksheets were developed to contain the title, goals to be achieved, and instructions for working. The worksheets developed also contain question exercises to improve students' thinking skills. The results of the worksheets validation are presented in Table 4.

Table 4. Results of Worksheets Validation

\begin{tabular}{cccccc}
\hline \multirow{2}{*}{ Rated aspect } & \multicolumn{5}{c}{ Assessment Score } \\
\cline { 2 - 6 } & V1 & V2 & V3 & V4 & V5 \\
\hline Contents Served & 3.5 & 2.5 & 3 & 4 & 4 \\
Language & 3 & 2 & 3 & 4 & 3.08 \\
\hline Average of All & Aspects: & 3.24 \\
Average of Percentage: & $81 \%$ \\
Category of Worksheets: & Appropriate \\
\hline
\end{tabular}




\section{Learning Media}

A simple terrarium was assembled to help the teacher in describing the global warming topic of study. The media can describe the global warming concept through practicum and simulation. The results of media validation are presented in Table 5.

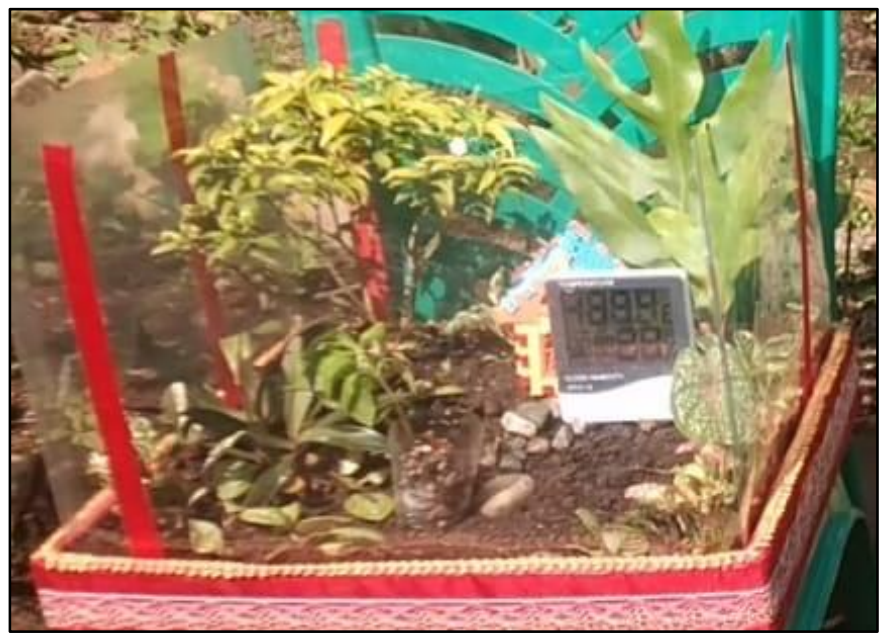

Figure 1. Simple Terrarium Media

Table 5. Results of Learning Media Validation

\begin{tabular}{cccccc}
\hline \multirow{2}{*}{ Rated aspect } & \multicolumn{5}{c}{ Assessment Score } \\
\cline { 2 - 6 } & V1 & V2 & V3 & V4 & V5 \\
\hline Theory & 4 & 4 & 4 & 3 & 4 \\
Illustration & 3 & 4 & 3 & 4 & 3 \\
Media Quality and Appearance & 4 & 4 & 2 & 3 & 2 \\
Attractiveness & 3 & 4 & 2 & 3 & 3 \\
\hline Average of All Aspects: 3.3 & & \\
Average of Percentage: 82.5\% & & \\
Category of Learning Media: Very Appropriate \\
\hline
\end{tabular}

The learning instruments were declared feasible and used in the learning process with a few revisions based on the validation results. The learning instruments developed include the guided inquiry learning model, which contains learning steps that include formulating problems, hypotheses, conducting experiments, collecting data, testing hypotheses, and drawing conclusions.

\section{Implementation and Evaluation Stages}

The developed learning instruments were validated and appropriate for the next stages, i.e., implementation and evaluation. Then, the implementation was conducted in 4 meetings, and the teacher delivered the lecture on the global warming topic using WhatsApp and Zoom meeting applications. Before the lecture, the students were given a pretest to measure their initial understanding of the concept. Subsequently, the learning video was uploaded on Youtube, which had the link distributed to students for learning purposes. Then, students learned the global warming experiments from the simulation using the simple terrarium teaching aid as recorded in the learning video during the learning process. They viewed the video, performed observation, and recorded their understanding on the worksheets. The results of students' work and assignments were uploaded to Google Classroom. The posttest was conducted at the final step, and the pretest and posttest scores were calculated and determined to measure learning instruments' effectiveness.

\section{Understanding of Concept}

Students are said to understand a concept if they can reach the concept understanding indicator. Ningsih (2019) states that there are three indicators of conceptual understanding, i.e., 1) students can interpret a concept using their language, 2) students can distinguish between examples of concepts that are related to the topics studied, and 3) students can conclude a concept without using certain symbols or 
images. The pretest and posttest values analysis showed that the n-gain percentage at a high category (0.76). A total of 14 students received high n-gain presentations, and 6 students received moderate $\mathrm{n}$-gain presentations. The average pretest score was 30, with the highest score of 37.5 and the lowest score of 17.5. All students did not pass the pretest score threshold. The posttest results obtained an average score of 82.8 with the highest score of 92.5 and the lowest score of 68.5 with 17 students passed and 3 students not passed.

The increase in the percentage value of students' understanding of concepts during the posttest shows that the learning processes were performed well, and students gained knowledge. This study results follow the research results by Amijaya et al. (2018), which states that the level of understanding of students who use guided inquiry learning shows a deeper level of knowledge since they are directly involved in finding answers to problems. A significant increase in value from pretest to posttest was obtained because students gained experience and images through the learning video, containing simple terrarium media to simulate the global warming processes. Students could stop, pause, and replay the learning video as they liked. Therefore, they could capture, store, and apply the concepts they learned in their memory. Thus, students were trained to be able to find for themselves various concepts that are studied thoroughly, meaningfully, and actively. This research result is also in line with Sudesti et al. (2014), which states that learning experiences can make it easier for students to understand and remember the material being studied because students will appreciate the process or activity being carried out more.

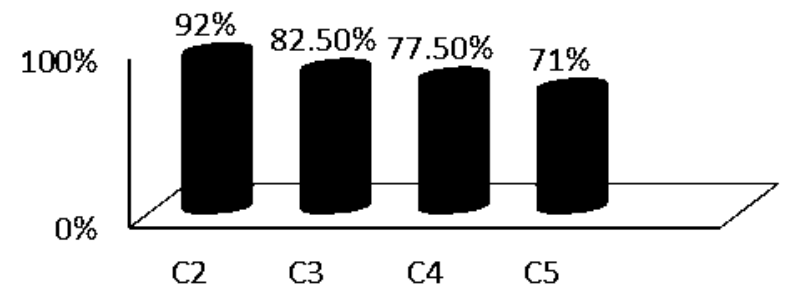

Figure 2. The Percentage of Students' Cognitive Ability

Figure 2 shows the results of students' cognitive abilities measurement. It can be concluded that their abilities in understanding the concept related to global warming were moderately high, ranging from $71 \%$ to $92 \%$ of C5 to C2 in Bloom's Taxonomy. The global warming topic requires high-order thinking skills to understand the concept since it is an abstract topic. Suranti et al. (2017) state that the high cognitive topics' low scores are related to high cognitive domains and high problem difficulty.

\section{Environmental Awareness of Student}

Students' environmental awareness was observed in each lesson using the observation sheet. The indicator of environmental awareness of students by Hening et al. (2013) are 1) keeping clean and not littering, 2) growing plants and animals, 3) not polluting the environment, (4) cleaning classrooms according to schedule, (5) cleaning classrooms before the learning, 6) cleaning the trash in the classroom before learning, 7) picking up and throwing away the garbage around the school, 8) taking care of plants in the surrounding environment. The results of observations of students' environmental awareness are presented in Figure 3.

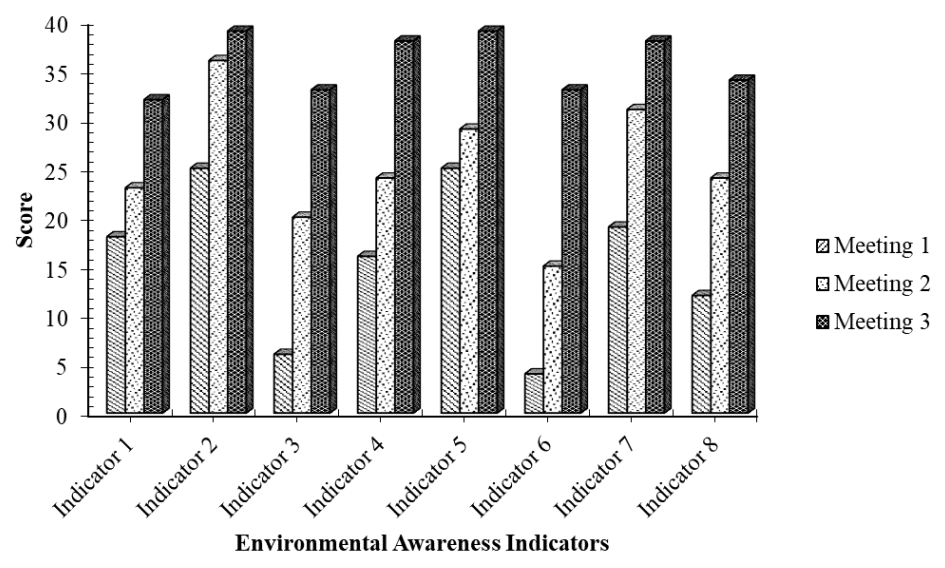

Figure 3. Students' Environmental Awareness 
Based on Figure 3, the character of the students' environmental awareness at each meeting always increases. The first meeting gained $39.06 \%$, then at the second and third meetings, the average percentage of students' environmental awareness characters increased at $63.12 \%$ and $89.37 \%$, respectively. The observation sheet assessment results also show that the character of environmental awareness appeared initially and increase at each meeting. The character of environmental awareness emerged when students made observations of global warming experiments using simple terrarium media. Using a simple terrarium as an experimental medium gave students an idea of the importance of protecting the environment and the impact of harmful behavior on the global warming phenomenon. Through these experiments, students were indirectly invited to understand their harmful behavior in the environment. Therefore, they gained knowledge and attitudes for protecting the environment. This research is in line with Siti and Qonita (2020) research, which states that individuals with good character can make decisions and are ready to be responsible for any consequences of their decisions. However, it takes time to go through the process to change someone's behaviors, and many factors influence it. The online learning implemented in this research is a limitation to fully delivering the study material to students. The teacher could not provide direct examples to instill environmental awareness deeper, while character building requires consistent exemplary transmission, training, and long-term habituation.

The learning process also requires parents' active role to provide good examples and teach children from an early age to foster good character in children. Apart from parents and teachers, other factors influencing students' environmental awareness are the community or peer environment. According to Monalisa (2016), the research results show that the environment and peers give the highest role in shaping students' character because, during adolescence, students get or spend more time interacting with their social environment or playgroups.

\section{CONCLUSION}

The development of the guided inquiry-based learning instruments assisted with simple terrarium was appropriate based on expert validation and could be implemented to teach the global warming study materials. Students' understanding of the concept has increased, as evidenced by the n-gain included in the high category. The character of students' environmental awareness is in a suitable category, and at each meeting, the character of environmental awareness has increased according to the results of observations.

\section{REFERENCES}

Amijaya, L. S., Ramdani, A., \& Merta, I. W. (2018). Pengaruh model pembelajaran inkuiri terbimbing terhadap hasil belajar dan kemampuan berpikir kritis peserta didik. Jurnal Pijar Mipa, 13(2), 94-99.

Cahayadi \& Ulung. (2015). Memulai Usaha Green Souvenir 30 Kreasi Bingkisan Istimewa. Jakarta: Gramedia Pustaka Utama.

Hening, W.R.N., Sudarmin, \& D. Mustikaningtyas. (2013). Pengembangan Modul Hubungan Antar Komponen Ekosistem berbantuan Flashcard untuk Menumbuhkan Karakter Cinta Lingkungan Pada Siswa SMP. Unnes Science Education Journal, 2(2), 254-261.

Ismail, S., M.H. Rahman, \& N. Muhammad. (2019). Pengaruh Model Pembelajaran Guided Inquiry terhadap Hasil Belajar Siswa pada Materi Momentum dan Impuls Kelas X MIA 5 SMA Negeri 1 Kota Ternate. Jurnal Pendidikan MIPA, 4(2), 31-36.

Martini. (2019). Hubungan antara Pengetahuan Lingkungan dengan Perilaku Prolingkungan Sekolah Adiwiyata. Rang Teknik Journal, 2(1), 71-78.

Monalisa, T.R. (2016). Peranan Lingkungan Sosial terhadap Pembentukan Sikap Peduli Lingkungan Siswa Di SMA Negeri Kabupaten Cianjur. Jurnal Pendidikan Geografi, 16(1), 44-55.

Ningsih, D. S. (2019). Meningkatkan Pemahaman Konsep IPA melalui Metode Demonstrasi Di Kelas VB SDN 61/X Talang Babat. Jurnal Gentala Pendidikan Dasar, 4(1), 22-40.

Rahman, A. (2019). Upaya Kepala Sekolah dalam Peningkatan Kemampuan Guru Memanfaatkan Media Pembelajaran dengan bantuan Teman Sejawat SDN 019 Galang Batam Tahun 2018. Jurnal Mitra Pendidikan (JMP Online), 3(3), 433-443. 
Sari, E.Y. (2019). Pengaruh Penggunaan Media Pembelajaran Buku Pop-Up terhadap Hasil Belajar Siswa Kelas IV SDN 2 Bendungan Kecamatan Gondang Kabupaten Tulungagung. Edustream: Jurnal Pendidikan Dasar, 3(2), 16-22.

Siti, B. \& Qonita, S. M. (2020). Penanaman CiLi (Cinta Lingkungan) Pada Siswa Melalui Program Lingkungan Sekolah Tanpa Sampah Plastik. Jurnal Pancar, 4(1), 11-16.

Sudesti, R., Sudargo, F., \& Nurjhani, M. K. (2014). Penerapan Pembelajaran Berbasis Praktikum untuk Meningkatkan Penguasaan Konsep dan Keterampilan Proses Sains Siswa SMP pada Subkonsep Difusi Osmosis. Formica Education Online, 1(1).

Suparmi, N. M. (2018). Hasil Belajar, Pemahaman Konsep dan Berpikir Kreatif Siswa dalam Pembelajaran Inkuiri Bebas dan Inkuiri Terbimbing. Journal of Education Technology, 2(4), $192-196$.

Suranti, N. M. Y., Gunawan, G., \& Sahidu, H. (2017). Pengaruh Model Project Based Learning Berbantuan Media Virtual Terhadap Penguasaan Konsep dan Kreativitas Fisika Siswa. Laboratorium Virtual dan Aplikasinya Dalam Pembelajaran. Mataram: Arga Puji Press.

Tanjung, H.S. \& Nababan, S.A. (2019). Pengembangan Perangkat Pembelajaran Berbasis Masalah untuk Meningkatkan Kemampuan Pemecahan Masalah dan Komunikasi Matematis Siswa SMA Negeri 3 Kuala Kabupaten Nagan Raya. Genta Mulia, 10(2), 178-187.

Widyawati, T., Adnyana, B. \& Warpala, S. (2019). Efektivitas Penerapan Model Pembelajaran Inkuiri Terbimbing Berbasis Pertanyaan terhadap Pemahaman Konsep IPA dan Keterampilan Proses Sains dalam Materi Interaksi Makhluk Hidup dengan Lingkungannya Di Kelas VII Di SMP Negeri 3 Banjar. Jurnal Pendidikan Biologi Undiksha, 6(2), 83-92.

Yunita, E. (2016). Pengembangan Perangkat Pembelajaran Menggunakan Model Inkuiri Terbimbing Topik Klasifikasi Makhluk Hidup Di SMP. Jurnal Inovasi Pembelajaran, 2(1), 282-292. 